\title{
Teaching NeuroImages: Rupture and spontaneous resolution of a P1 perforator pseudoaneurysm
}

Enrico Giordan, Alejandro A. Rabinstein, MD, Harry J. Cloft, MD, PhD, and Giuseppe Lanzino, MD Neurology ${ }^{\circledR}$ 2018;90:e1730-e1731. doi:10.1212/WNL.0000000000005485

\section{Correspondence}

Dr. Lanzino

Lanzino.giuspeppe@

mayo.edu
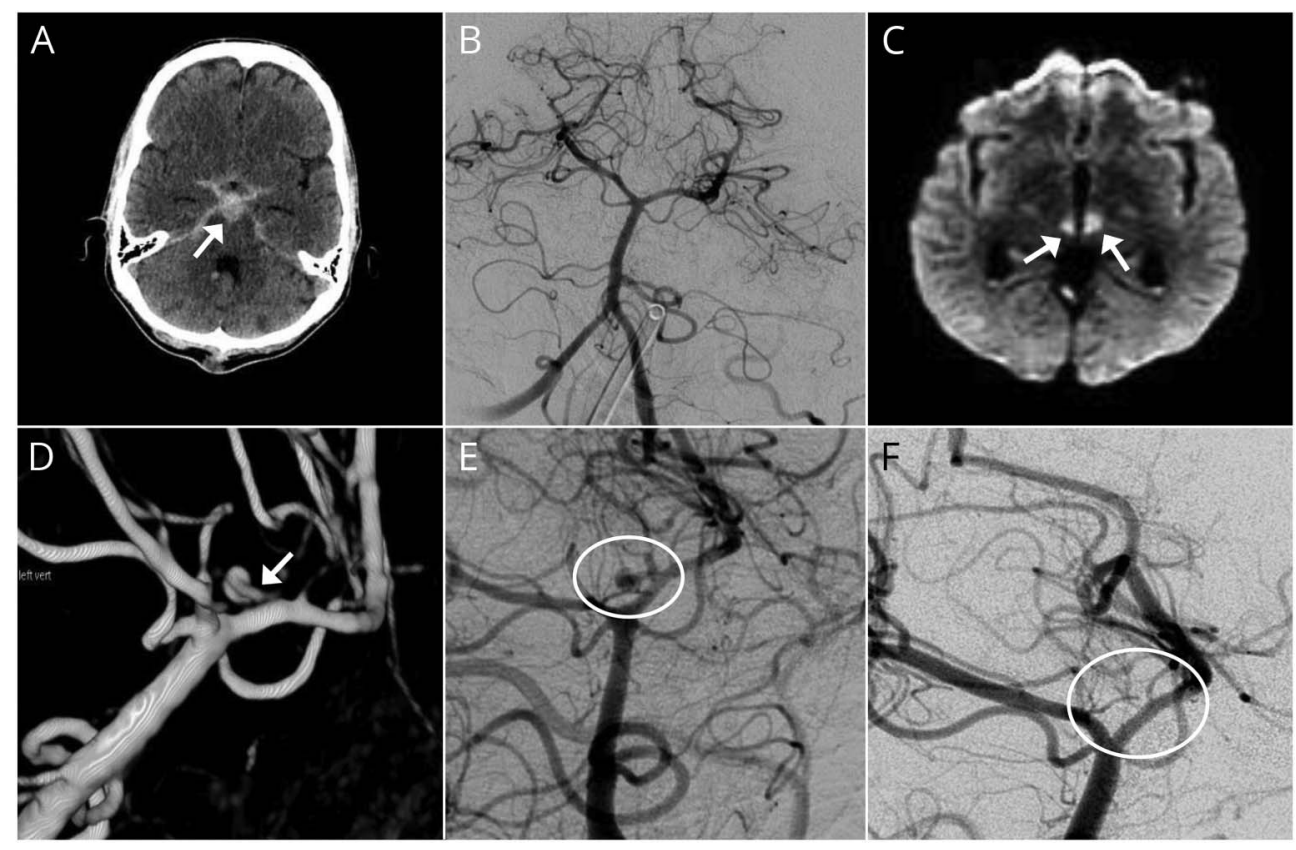

(A) Admission $\mathrm{CT}$ shows subarachnoid hemorrhage (arrow). (B) Initial catheter angiography shows no visible abnormalities. (C) Brain MRI DWI shows bilateral thalamic infarcts (arrows). (D) Follow-up angiography, 3D reconstruction, demonstrates a $2 \mathrm{~mm}$ pseudoaneurysm arising from a large left thalamoperforator (arrow). (E) 2D of the same study. (F) Angiography 6 weeks after presentation documents spontaneous resolution of the pseudoaneurysm (circle).
A 47-year-old man with a history of smoking and hypertension had a severe, sudden headache. Head CT showed subarachnoid hemorrhage ( $\mathrm{SAH}$ ) (figure, A). Progressive ophthalmoplegia developed without alteration of consciousness. Catheter angiography was normal (figure, B). Brain MRI documented bilateral thalamic infarcts (figure, C). Repeat catheter angiography after 4 days showed a 2-mm dissecting pseudoaneurysm of a thalamoperforator (figure, D and E). Serial noninvasive vascular studies documented no growth. Six weeks later, a catheter angiogram demonstrated complete resolution of the pseudoaneurysm (figure, F).Bilateral third nerve palsy persisted at 1 year follow-up. Dissecting pseudoaneurysms of perforating posterior circulation vessels can present with a pattern suggestive of perimesencephalic SAH. Presence of associated neurologic deficits should increase the level of suspicion. Spontaneous resolution can occur without invasive treatment. ${ }^{1}$

\section{MORE ONLINE}

\section{$\rightarrow$ Teaching slides}

links.lww.com/WNL/A427 


\section{Author contributions}

Enrico Giordan: manuscript preparation, drafting manuscript, collection of data and figure, approval of final version. Alejandro A. Rabinstein: collection of data, preparation of manuscript, critical review and approval of the final version. Harry Cloft: collection of data, critical review and final approval of the manuscript. Giuseppe Lanzino: manuscript preparation, drafting manuscript, collection of data and figure, approval of final version.

\section{Study funding}

No targeted funding reported.

\section{Disclosure}

The authors report no disclosures relevant to the manuscript. Go to Neurology.org/N for full disclosures.

\section{Reference}

1. Park SQ, Kwon OK, Kim SH, Oh CW, Han MH. Pre-mesencephalic subarachnoid hemorrhage: rupture of tiny aneurysms of the basilar artery perforator. Acta Neurochir 2009; 151:1639-1646. 


\section{Neurology}

\section{Teaching NeuroImages: Rupture and spontaneous resolution of a P1 perforator pseudoaneurysm}

Enrico Giordan, Alejandro A. Rabinstein, Harry J. Cloft, et al.

Neurology 2018;90;e1730-e1731

DOI 10.1212/WNL.0000000000005485

\section{This information is current as of May 7, 2018}

\section{Updated Information \& Services}

References

Subspecialty Collections

Permissions \& Licensing

Reprints including high resolution figures, can be found at: http://n.neurology.org/content/90/19/e1730.full

This article cites 1 articles, 0 of which you can access for free at: http://n.neurology.org/content/90/19/e1730.full\#ref-list-1

This article, along with others on similar topics, appears in the following collection(s):

All Cerebrovascular disease/Stroke

http://n.neurology.org/cgi/collection/all_cerebrovascular_disease_strok e

Other cerebrovascular disease/ Stroke

http://n.neurology.org/cgi/collection/other_cerebrovascular_disease_s troke

Information about reproducing this article in parts (figures,tables) or in its entirety can be found online at:

http://www.neurology.org/about/about_the_journal\#permissions

Information about ordering reprints can be found online:

http://n.neurology.org/subscribers/advertise

Neurology ${ }^{\circledR}$ is the official journal of the American Academy of Neurology. Published continuously since 1951, it is now a weekly with 48 issues per year. Copyright @ 2018 American Academy of Neurology. All rights reserved. Print ISSN: 0028-3878. Online ISSN: 1526-632X.

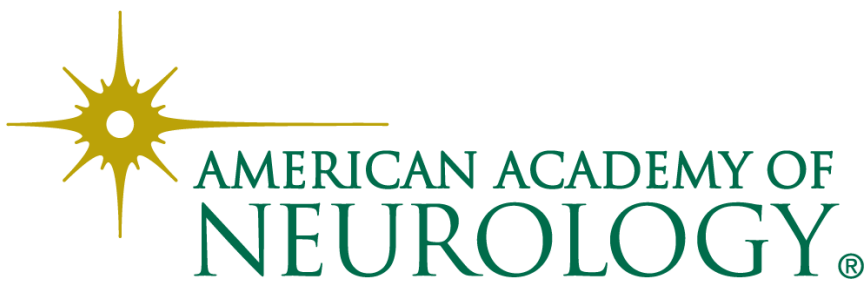

